\title{
Capelin Mallotus villosus (Pisces: Osmeridae), glaciations, and speciation: a nomothetic approach to fisheries ecology and reproductive biology
}

\author{
Konstantinos I. Stergiou* \\ Institute of Oceanography, McGill University, 3620 University Street, Montreal, Canada
}

\begin{abstract}
Capelin Mallotus villosus in the North Pacific and Northwest Atlantic are characterized by a wider latitudinal distribution (cool temperate to subarctic), lower number of vertebrae (64.45 to 68.50 ), lower biomass, lower fecundity and larger eggs than are capelin in the Central-Northeast Atlantic (exclusively subarctic, 69.16 to 71.54 vertebrae). Capelin in the North Pacific and Northwest Atlantic spawn intertidally over a wider range of latitudes $\left(42\right.$ to $72^{\circ} \mathrm{N}$ ), temperatures $\left(1\right.$ to $14^{\circ} \mathrm{C}$ ), salinities (from brackish to oceanic water), and at a higher mean temperature $\left(7.5^{\circ} \mathrm{C}\right)$, than do populations in the Central and Northeast Atlantic (offshore spawning, 63 to $76^{\circ} \mathrm{N}, 0.94$ to $7^{\circ} \mathrm{C}, 32.0 \%$ to $34.6 \% 4^{\circ}{ }^{\circ} \mathrm{C}$ respectively). These differences indicate that capelin are towards the r-endpoint of the $\mathrm{r}-\mathrm{k}$ continuum of life history strategies in the North Pacific-Northwest Atlantic and towards the k-endpoint in the Northeast Atlantic. A nomothetic explanation is proposed. During the peak of the last glaciation, the major present-day spawning grounds on the Pacific rim were ice-free. Capelin experienced little change in their accustomed enviromental conditions and spawned intertidally over a wide geographic range. In contrast, North Atlantic spawning grounds were ice-covered. Accordingly, offshore spawning habits evolved. Intertidal spawning in the North Atlantic probably did occur between 40 to $55^{\circ} \mathrm{N}$ along the European coast and in the Mediterranean Sea where ice did not reach the sea. Capelin populations underwent k-selection, and stenothermy, stenohalinity, low fecundity, large egg size and high biomass evolved in populations of deep-spawning capelin of the North Atlantic in response to the greater environmental predictability in these offshore habitats. During the Holocene hypsithermal, capelin from the Pacific Ocean (intertidal spawning) repopulated Canadian Arctic waters and Northwest Atlantic. Deep-spawning capelin continued to reproduce in the North Atlantic where bathymetry, spawning temperatures and salinities were optimum (Grand Banks, Iceland, Barents Sea). Minor stocks of beachspawning capelin which now inhabit some Norwegian fjords may have been derived from the Northwest Atlantic, via the North Atlantic Drift, and/or from relict populations which spawned intertidally along the ice-free Western European/Mediterranean coast. The implications of this hypothesis for the taxonomic status of capelin are discussed.
\end{abstract}

\section{INTRODUCTION}

Capelin Mallotus villosus inhabit arctic, subarctic and cool-temperate seas (Walters 1955, McAllister 1963, 1984, Winters 1969, Jangaard 1974, Stergiou 1984) and play a key role in the North Atlantic ecosystem (Zenkevitch 1963, Bailey et al. 1977). They have been fished by many generations of Canadian, Greenlandic, Icelandic, Norwegian and Murman fishermen, and continue to play a major role in the North Atlantic fishery (Perley 1859, Hardy 1867, Sars 1879, Fries et al.

- Present address: National Centre for Marine Research, Agios Kosmas, Hellenikon, Athens 16604, Greece
1895, Hjort 1914, Jensen 1925, Prokhorov 1965, Vibe 1967, Corlett 1968, Vilhjálmsson 1968, 1983, Mattox 1973, Cumming 1975, Winters 1975, Stergiou 1984). The capelin fishery presently ranks fourth in world fishery production, with a catch of $2265039 \mathrm{t}$ in 1985 (FAO 1987).

There are signs of genetic differentiation of capelin throughout its georgraphic range. The differences abserved in some morphometric and meristic characters between the populations of capelin in the North Pacific and Atlantic Oceans have been used to argue for the recognition of 2 subspecies, one in each ocean (Vladykov 1933, Schultz 1937, Rumyantsev 1946, Schmidt 1965, Kljukanov 1972, Kljukanov \& McAllister 
1979). In addition, the spawning mode of capelin in the Barents Sea differs from that in the Northwest Atlantic (Prokhorov 1965, Templeman 1968, Stergiou 1984).

Glacial-interglacial cycles have been widely considered as factors affecting the distribution, abundance and speciation of both marine (e.g. Slobodkin \& Rapport 1974, Grant \& Utter 1984, Nesis 1984, Scott et al. 1986) and land biota (Gould 1969, Budyko 1974, 1977). Here, the distribution, meristic characters, abundance, spawning conditions, fecundity and egg size of capelin are reviewed and differences between the populations of capelin in the North Pacific-Northwest Atlantic and Central-Northeast Atlantic are established. These differences are heuristically correlated with the changes in oceanographic conditions of the Northern Hemisphere which occurred during the last glacialinterglacial cycle. These patterns are then used to develop a nomothetic (sensu Raup \& Gould 1974) approach to fisheries ecology and reproductive biology. The implications of this hypothesis for the taxonomic status of capelin are also discussed.

\section{DISTRIBUTION}

The distribution of capelin in the North Atlantic ocean (Fig. 1) coincides with that of the marine subarctic zone, sensu Dunbar (1951, 1968, 1972), that is, the

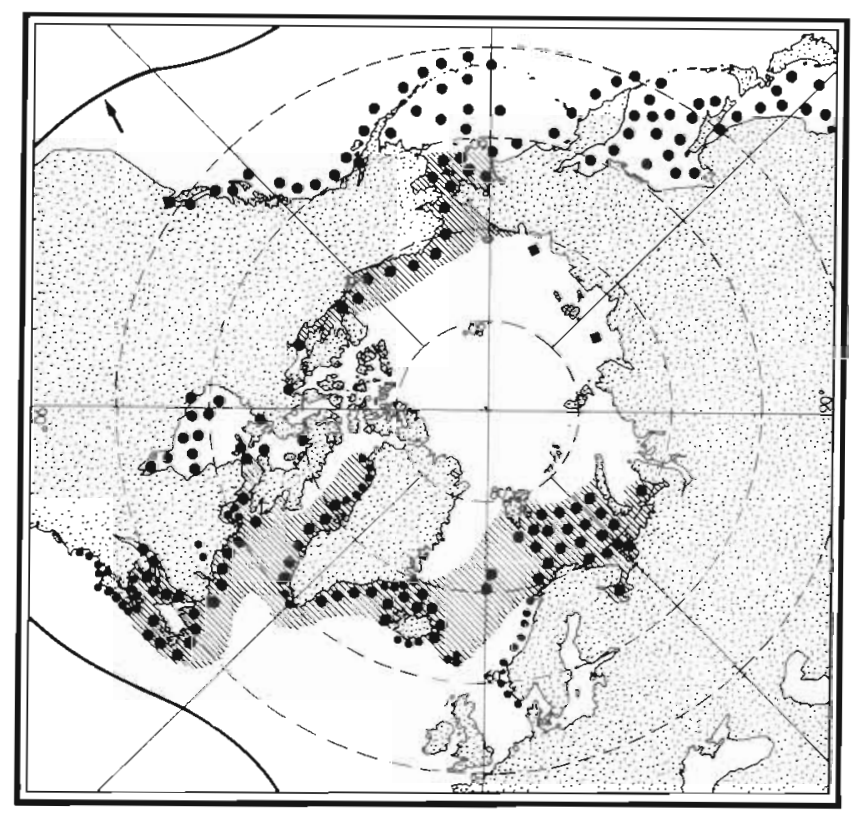

Fig. 1. Map showing the Ortmann line (heavy line marked with an arrow) and the marine subarctic zone in the world ocean (hatched area, reproduced from Dunbar 1968) together with the distribution of capelin (from Stergiou 1984, unpubl.): (-) areas visited on a year-to-year basis; $(\bullet)$ areas visited occasionally; ( $)$ areas where it is not known whether capelin is permanent or a periodic visitor zone in which water from the Arctic Ocean is found mixed, or in close association with, water from the Atlantic Ocean, and extends vertically to 250 or $300 \mathrm{~m}$ depth (Stergiou 1984, unpubl.). In the Pacific (Fig. 1), the distribution of capelin is mainly within the cool-temperate zone (McAllister 1963, Stergiou 1984, unpubI.) the southern limit of which is bounded by the $15^{\circ} \mathrm{C}$ isotherm (Ortmann line; Ortmann 1896). The distribution of capelin in the Arctic Ocean is discontinuous and Arctic populations are probably relicts from preceding warm periods (Stergiou 1984, unpubl.). Thus, in the North Pacific and Northwest Atlantic capelin occupy a wider area (cool-temperate, subarctic) than they do in the Central and Northeast Atlantic (exclusively subarctic).

\section{SYSTEMATIC POSITION, NUMBER OF VERTEBRAE}

Capelin belongs to the Suborder Salmonoidea and together with the smelts comprises the Family Osmeridae (McAllister 1963). Pacific and Atlantic populations are meristically and morphometrically different and may represent either 2 distinct subspecies (Vadykov 1933, Schultz 1937, Rumyantsev 1946. Schmidt 1965, Kljukanov 1972, Kljukanov \& McAllister 1979 ) or one monotypic species with 2 consubspecific forms in each ocean (McAllister 1963, 1984, Kljukanov \& McAllister 1979)

There is an increase in the number of vertebrae from south to north (Table 1), which is not well correlated with environmental temperatures (Pitt 1958, Prokhorov 1965, 1968, Templeman 1968, Vilhjálmsson 1968). This is clearly shown by the similarity in the number of vertebrae in populations from the Grand Banks and the Newfoundland/Labrador/Gulf of St. Lawrence, regions with dissimilar ambient temperatures, and by the differences in number of vertebrae between capelin from the Barents Sea and those from the Grand Banks, regions with similar ambient temperatures. Templeman (1968) and Vilhjálmsson (1968) maintained that genetic differences may account for the differences in the vertebral counts

What is evident (Table 1), however, is that the number of vertebrae of capelin in the North Pacific and Northwest Atlantic ranges between 64.45 and 68.50, as opposed to 69.16 to 71.54 in populations from the Central-Northeast Atlantic (Barents Sea and Iceland). These distributions are non-overlapping.

\section{BIOMASS}

\section{Landings}

Over the last 15 to $20 \mathrm{yr}$, capelin have been heavily exploited by Norwegian and Soviet fleets in the 


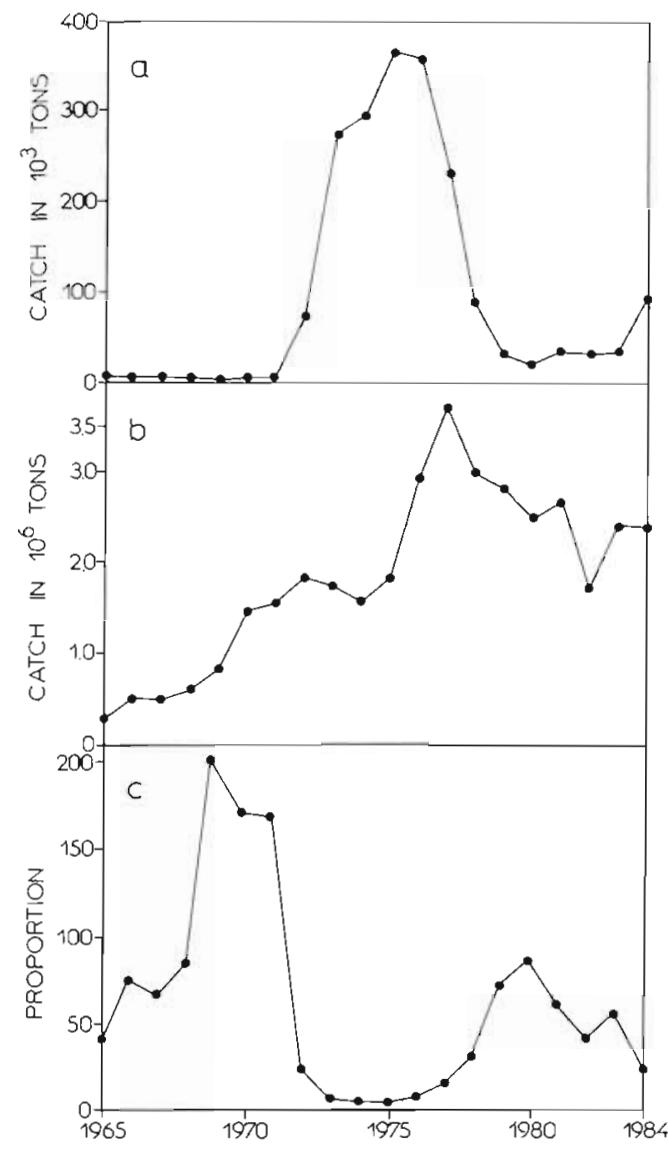

Fig. 2. Mallotus villosus. Catches of capelin in (a) North Pacific and Northwest Atlantic; (b) Northeast Atlantic; (c) proportion of the catches in (NE Atlantic)/(N Pacific + NW Atlantic)

night; eggs adhere to the gravel and are buried in the substrate to depths of 15 to $20 \mathrm{~cm}$ by wave and tidal action. In areas where beach-spawning takes place, capelin may also enter rivers as for instance in Northwest River, Labrador (Kendall 1909, Backus 1957), St. Lawrence River, Quebec (Parent \& Brunel 1976), Tumen River, Korea (Mori 1930), rivers entering the Gulf of Maine (Huntsman 1922, Bigelow \& Welsh 1924), and in some rivers of the Sakhalin island (Vel-
Table 2. Mallotus villosus. Areas where the abundance and distribution of capelin have been shown to be greatly affected by hydrometeorological processes

\begin{tabular}{|c|c|}
\hline Area & Source \\
\hline Barents Sea & $\begin{array}{l}\text { Konstantinov (1965), Prokhorov (1965, } \\
\text { 1968), Corlett (1968), Konstantinov \& } \\
\text { Svetlov (1974), Loeng et al. (1983), Ster- } \\
\text { giou (1984), Ozhigin \& Luka (1985), Ozhi- } \\
\text { gin \& Ushakov (1985), Gjøsæeter \& Loeng } \\
\text { (1987) }\end{array}$ \\
\hline Ungava Bay & Dunbar $(1976,1983)$ \\
\hline Greenland & $\begin{array}{l}\text { Jensen }(1939,1948) \text {, Hansen \& Hermann } \\
\text { (1953), Vibe (1967), Stergiou (1984) }\end{array}$ \\
\hline Iceland & $\begin{array}{l}\text { Saemundsson (1934), Jensen (1939, } \\
\text { 1948), Fridriksson (1948), Tåning (1948), } \\
\text { Magnusson (1966, 1968), Malmberg } \\
\text { (1983) }\end{array}$ \\
\hline Newfoundland & $\begin{array}{l}\text { Templeman \& Fleming (1953), Frank \& } \\
\text { Leggett (1981a, b, 1982a, b), Leggett et al. } \\
\text { (1984) }\end{array}$ \\
\hline $\begin{array}{l}\text { Gulf of Maine/ } \\
\text { Bay of Fundy }\end{array}$ & $\begin{array}{l}\text { Kendall (1917, 1919), Bigelow \& Welsch } \\
\text { (1924), Bigelow \& Schroeder (1953), Tay- } \\
\text { lor et al. (1957), Bigelow (1963) }\end{array}$ \\
\hline Japan Sea & Rumyantsev (1946), Velikanov (1987) \\
\hline Korea & Stergiou (1984) \\
\hline
\end{tabular}

ikanov 1984). Offshore, spawning takes place on the bottom in areas with coarse gravel. In the Barents Sea (Sætre \& Gjøsæeter 1975), White Sea (Altukhov 1977) and around Iceland (Thors 1981) these areas have been shown to have well-developed bottom currents.

It is evident (Table 4) that capelin in the North Pacific, Northwest Atlantic (except the populations on the Grand Banks and, sporadically, on the southwest coast of Newfoundland) and in the waters off West Greenland spawn on intertidal beaches and enter rivers quite frequently. In the Central-Northeast Atlantic (Iceland and Barents Sea, except minor stocks in some Norwegian fjords) spawning takes place in deep waters offshore.

Table 3. Mallotus villosus. Biomass estimates of capelin (in millions of tons) in the North Atlantic

\begin{tabular}{|c|c|c|c|c|}
\hline Location & Biomass & Method & Period & Source \\
\hline Barents Sea & $0.8-10.1$ & Acoustic & $1973-75$ & $(1)-(3)$ \\
\hline Iceland & $0.6-1.5$ & Acoustic & $1980-83$ & $(4)-(7)$ \\
\hline \multirow[t]{2}{*}{ Labrador/Newfoundland ${ }^{a}$} & $1.3-4.8$ & Sequential model & $1972-78$ & (8) \\
\hline & & Photogrammetric & 1974 & (9) \\
\hline Grand Banks & 1 & Photogrammetric & 1977 & $(10)$ \\
\hline \multicolumn{5}{|l|}{ - $2 J 3 \mathrm{~K}$ NAFO Div. } \\
\hline \multicolumn{5}{|c|}{$\begin{array}{l}\text { Sources: (1) Dragesund et al. (1973); (2) Nakken \& Dommasnes (1975); (3) Midttun \& Nakken (1977); (4) Vilhjálmsson (1983); } \\
\text { (5) Vilhjálmsson (1984); (6) Vilhjálmsson (1985); (7) Vilhjálmsson (1986); (8) Serebrov et al. (1975); (9) Miller \& Carscadden } \\
\text { (1979); (10) Klochkov \& Seliverstov (1978) }\end{array}$} \\
\hline
\end{tabular}


Table 6. Mallotus villosus. Temperatures of spawning time of capelin in different areas

\begin{tabular}{|c|c|c|c|}
\hline Location & Lat. ${ }^{\circ} \mathrm{N}$ & $\mathrm{T}^{\circ} \mathrm{C}$ & Source \\
\hline Grand Banks & $43-45$ & $1-4.7$ & $(1)-(4),(40)$ \\
\hline Gulf of St. Lawrence & $48-50$ & $6-9$ & (5) \\
\hline \multicolumn{4}{|l|}{ Newfoundland } \\
\hline West coast & $48-52$ & $6-9$ & (5) \\
\hline East and south coasts & $46-51$ & $5.5-10.7$ & $(6)-(9)$ \\
\hline Labrador & $52-58$ & $5.5-8.5$ & $(6),(7)$ \\
\hline \multicolumn{4}{|l|}{ Hudson Bay } \\
\hline Richmond Gulf & $52-56$ & 10 & $(10)$ \\
\hline \multicolumn{4}{|l|}{ Beaufort Sea } \\
\hline Herchel Island & $69-70$ & $2.3-9.5$ & $(11)$ \\
\hline \multicolumn{4}{|l|}{ British Columbia } \\
\hline Georgia Strait & $48-55$ & $10-12.5$ & $(12),(13)$ \\
\hline \multicolumn{4}{|l|}{ Okhotsk Sea } \\
\hline Shantar Island & 55 & 12.9 & (14) \\
\hline Eastern part & $55-60$ & $6-7.8$ & (15) \\
\hline \multicolumn{4}{|l|}{ Sakhalin } \\
\hline West, south and east coasts & $46-52$ & $2-14$ & $(16)$ \\
\hline \multicolumn{4}{|l|}{ Japan Sea } \\
\hline Peter The Great Bay & $42-44$ & $2-4$ & $(17)$ \\
\hline \multicolumn{4}{|l|}{ Barents Sea } \\
\hline Norwegian coast & $67-72$ & $1.5-6.5$ & $(18)-(23),(41)$ \\
\hline Western Murman coast & $67-72$ & $1.2-3$ & $(24)-(30)$ \\
\hline Eastern Murman coast & $67-72$ & $2.2-4.9$ & $(24)$ \\
\hline White Sea & $64-66$ & $>2$ & (31) \\
\hline Estuary of the White Sea & $66-68$ & $0.94-0.96$ & $(24)$ \\
\hline West Greenland & $60-70$ & $1.9-8.5$ & $(32)-(34)$ \\
\hline Iceland & $63-66$ & $5-7$ & $(35)-(39)$ \\
\hline \multicolumn{4}{|c|}{ 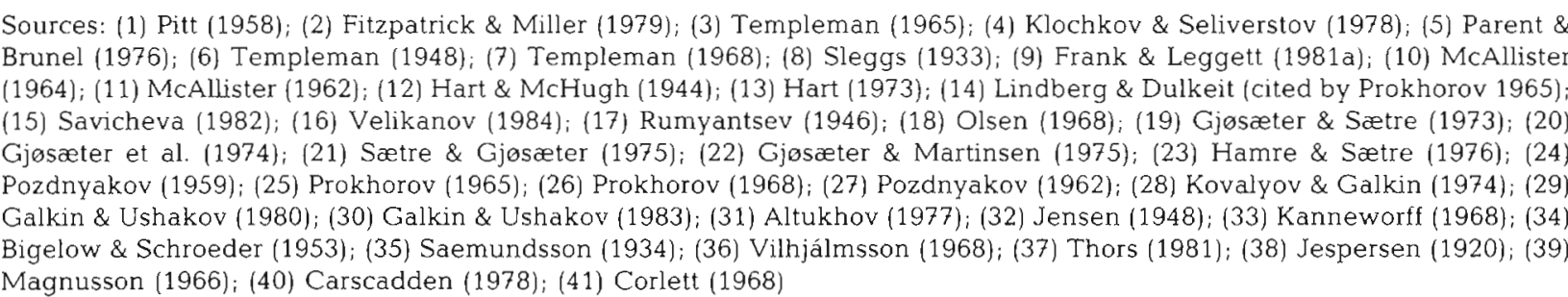 } \\
\hline
\end{tabular}

Table 7. Mallotus villosus. Salinities at spawning time of capelin in different areas

\begin{tabular}{|lrrr|}
\hline Location & Lat. ${ }^{\circ} \mathrm{N}$ & Salinity $(\%)$ & Source \\
\hline Sakhalin & $46-52$ & $3.04-33.00$ & $(1)$ \\
Newfoundland & $43-55$ & $14.00-33.00$ & $(2)$ \\
Barents Sea & $67-72$ & $32.00-34.60$ & $(3)-(5)$ \\
& & & \\
Sources: (1) Velikanov (1984); (2) Templeman (1948); (3) \\
Rass (1933); (4) Prokhorov (1965); (5) Sætre \& Gjøsæter \\
(1975)
\end{tabular}

\section{FECUNDITY AND EGG SIZE}

Although both ovaries of capelin have similar rates of egg development, the left ovary is several times larger than the right one (Winters 1971, Podznyakov 1957).
The available data on the mean (right and left ovary) fecundity and egg diameter of capelin from various areas of their range (Table 8 ) indicate that the populations of capelin in the Central-Northeast Atlantic (Barents Sea and Iceland) are characterized by lower fecundity and larger eggs than are populations in the Northwest Atlantic and Northeast Pacific. The estimations given by Hart \& McHugh (1944) for Northwest Pacific populations were based on specimens shorter than $12.2 \mathrm{~mm}$ while the other estimates were based on specimens with lengths between 13 and $20 \mathrm{~mm}$. Hence comparisons cannot be made.

\section{DISCUSSION}

To sum up, capelin in the North Pacific and Northwest Atlantic differ from the Central-Northeast Atlantic 
Table 8. Mallotus villosus. Fecundity and egg diameter (in $\mathrm{m} . \mathrm{m}$ ) of capelin in different areas

\begin{tabular}{|c|c|c|c|}
\hline Location & Fecundity & Egg diameter & Source \\
\hline British Columbia & $3020-6670$ & & (1) \\
\hline Japan Sea & $5400-50700$ & $0.65-0.82$ & (2) \\
\hline Okhotsk Sea & $6000-53200$ & $0.75-0.86$ & $(2),(3)$ \\
\hline Newfoundland & $18607-47859$ & 0.97 & (4) \\
\hline Grand Banks & $16550-61500$ & & (5) \\
\hline Iceland & & 1.12 & (6) \\
\hline Barents Sea & $9000-24569$ & 1.17 & (7)-(9) \\
\hline \multicolumn{4}{|c|}{$\begin{array}{l}\text { Sources: (1) Hart \& McHugh (1944); (2) Velikanov (1987) } \\
\text { (3) Savicheva (1975); (4) Templeman (1948); (5) Winters } \\
\text { (1971); (6) Fredriksson \& Timmerman (cited by Winters } \\
\text { 1971); (7) Pozdnyakov (1957); (8) Gjøsæter \& Monstad } \\
\text { (1973); (9) Galkin \& Kovalev (1975) }\end{array}$} \\
\hline
\end{tabular}

capelin in: (1) the climatic zones occupied, (2) number of vertebrae, (3) level of biomass, (4) range of latitude for spawning, (5) spawning depth, (6) range of spawning salinities, (7) range of spawning temperatures, (8) mean spawning temperature, (9) fecundity and egg size and (10) predictability of the spawning habitat (Table 9). These differences indicate that the populations of capelin in the North Pacific-Northwest Atlantic are towards the $r-e n d p o i n t ~ o f ~ t h e ~ r-k$ continuum of life history strategies, first described by MacArthur \& Wilson (1967) and developed further by Pianka (1970). The opposite seems to be true of the populations of capelin in the Central-Northeast Atlantic.

Differential reproduction, in particular, is essential to the $\mathrm{r}$ - and k-selection argument (Pianka 1970, Colinveaux 1986). Small-egg strategy is well suited to opportunist, $\mathrm{r}$-selected populations (energy is mainly allotted to reproduction and less to structures and habits that mediate persistence and competitive abilities). Rstrategists inhabit immature, highly variable, unpredictable environments (e.g. upwellings, intertidal and estuarine regions) and their population size is usually below the carrying capacity of the environment. Largeegg strategy, on the other hand, is well suited to kselected populations (energy is mainly allocated to non-reproductive activities that promote individual survival). K-strategists occupy mature, relatively stable and predictable environments (e.g. coral reefs, deepsea) and are characterized by population sizes near the carrying capacity of the environment. Although for terrestrial organisms a clear distinction between the 2 strategies can be made in some instances, fish show the full range of the $\mathrm{r}-\mathrm{k}$ continuum (Pianka 1970).

Historical factors may account for these geographic differences in the ecology and reproductive biology of capelin. Climatic changes have occurred in the past in a considerable array of different time scales. Setting aside the periodicity of the major ice ages, a matter of 250 to 300 million yr, the current period of Pleistocene glaciations has existed for at least 2 million yr (Mason 1976, Matthews 1976. Boellstorff 1978) and has been repeatedly interrupted by interglacial warm epochs, each glacial stage lasting about 100000 yr (Emiliani 1972). Paleoclimatic data suggest that the last glaciation started some 70000 to 75000 yr ago (Grootes 1978, Stuiver et al. 1978, Woillard \& Mook 1982) and reached a maximum some 18000 years ago (CLIMAP 1976 , Barash \& Os'kina 1979, Berger et al. 1985).

During the peak of the last glacial stage, ice sheets in the North Pacific existed only along the northeastern edge of the ocean basin from the Aleutian Islands to Washington and portions of the Kamtchatka Peninsula

Table 9. Mallotus villosus. Summary of differences in various aspects of capelin biology and ecology between North PacificNorthwest Atlantic (NP-NWA) and Central-Northeast Atlantic (C-NEA)

\begin{tabular}{|lll|}
\hline Aspects & \multicolumn{1}{c}{ NP-NWA } & C-NEA \\
\hline Distribution & Cool-temperate and subarctic & Exclusively subarctic \\
Number of vertebrae & $64.45-68.50$ & $69.16-71.54$ \\
Abundance & & \\
Mean 1964-1985 & $103237 \mathrm{t}$ & $1890927 \mathrm{t}$ \\
commercial catch & & \\
Spawning & $42-72^{\circ} \mathrm{N}$ & $63-76^{\circ} \mathrm{N}$ \\
Latitude & Intertidal & Offshore deep water $^{\circ}$ \\
Depth & Low & $0.94-7^{\circ} \mathrm{C}$ \\
Predictability of habitat & $1-14^{\circ} \mathrm{C}$ & $4^{\circ} \mathrm{C}$ \\
T meange & $7.5^{\circ} \mathrm{C}$ & $32-34.6 \%$ \\
Salinity & From brackish to oceanic & $<30000$ eggs \\
Fecundity & $<65000$ eggs & $>1 \mathrm{~mm}$ \\
Egg size & $<1 \mathrm{~mm}$ & \\
\hline
\end{tabular}


(Fig. 3a; Hopkins 1972, Nesis 1984). Yet, glacial biotic refugia seem to have existed along the eastern Pacific coast (Warner et al. 1982). The major present-day spawning grounds of capelin on the Pacific rim were ice-free. In addition, glacial sea surface temperatures (Fig. 3a) did not differ considerably from present ones (Fig. 3b). Hence during the last glaciation, capelin in these regions experienced little change in the environmental conditions to which they were previously accustomed.

In contrast, the shelf of the North Atlantic was covered by ice (Fig. 3a; Barash \& Os'kina 1979, Nesis 1984). Glaciers descended deep into the ocean except in discrete areas between glaciers and along the northern boundary of the boreal region, e.g. along the slope of George Banks, south of the Grand Banks and Iceland, and southwest of the Celtic Sea (Nesis 1984). Hence, during the maximum of the last glaciation (and/ or probably during any other Pleistocene glacial stage), present day spawning grounds of capelin were icecovered. Accordingly, offshore spawning habits evolved. Beach spawning probably did not occur along the western rim of the Atlantic basin. Intertidal spawning in the western Atlantic would have been restricted to areas south of $40^{\circ} \mathrm{N}$, which were washed by the ancestral Gulf Stream (Barash \& Os'kina 1979), with waters too warm for survival. Intertidal spawning in the Eastern Atlantic probably did occur between 40 and $55^{\circ} \mathrm{N}$ along the European coast. In addition, intertidal spawning probably occurred in the Northwest and Northern Mediterranean Sea where glacial temperatures were comparable to those in adjacent areas of the northeastern Atlantic (Thiede 1978), and Pleistocene capelin fossils have been found in Bosnia, Yugoslavia (McAllister 1963). However, the dominant mode of spawning for Atlantic capelin during the last glaciation was probably offshore at depth, across the entire North Atlantic, in a relatively cold zone where the range of temperature and salinity was considerably smaller than in coastal areas. Spawning at depth favored selection toward stenothermy and stenohalinity. Yet, lower fecundity and larger egg size were favored because of the greater environmental predictability of these offshore habitats (Sanders 1968, Slobodkin \& Sanders 1969, Grassle \& Sanders 1973, Thiery 1982). Increased environmental stability, in addition, has been argued to bring about a decrease in expenditure of energy for regulatory purposes and therefore more energy is available for production and, thus, for biomass (Connell \& Orias 1964, Pianka 1970). Hence, spawning at depth favored k-selection.

With the opening of the Bering Strait and the warming up of the Canadian Arctic Archipelagos during the Holocene hypsithermal, capelin from the Pacific Ocean (intertidal spawning) repopulated the Canadian Arctic waters and Northwest Atlantic. However, deep spawning capelin continued to populate areas where bathymetry and spawning temperatures and salinities were optimum (Grand Banks, Iceland, Barents Sea). Minor beach-spawning capelin stocks inhabiting some Norwegian fjords may have been derived from the Northwest Atlantic, via the North Atlantic Drift, and/or from beach spawning populations inhabiting the icefree Western European/Mediterranean coast. The

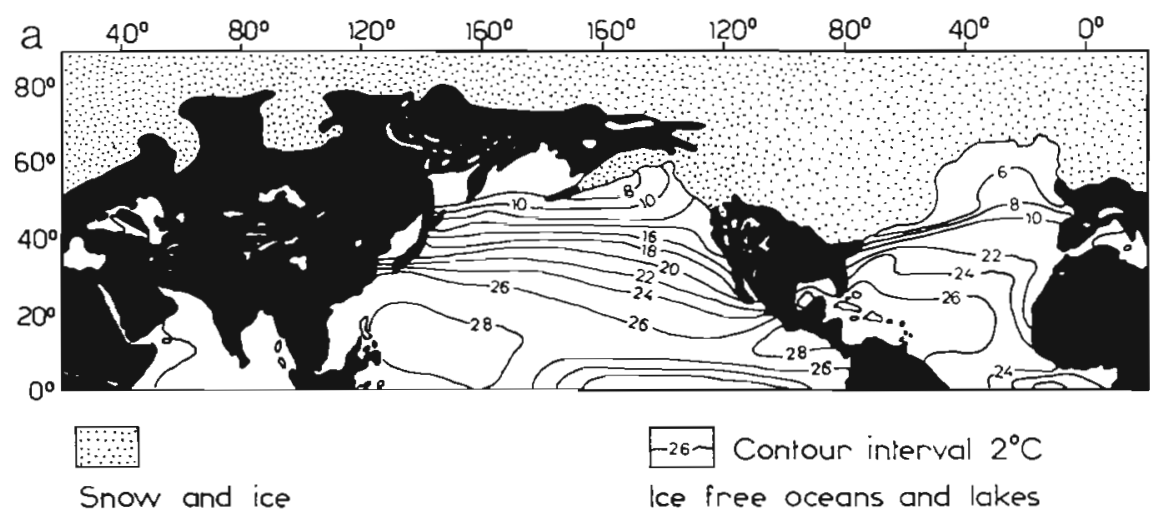

Fig. 3. (a) Sea-surface temperature and ice extent for Northern Hemisphere in August 18000 yr Before Present (reproduced from CLIMAP 1976); (b) present day sea-surface temperature in August (from Harvey 1976)

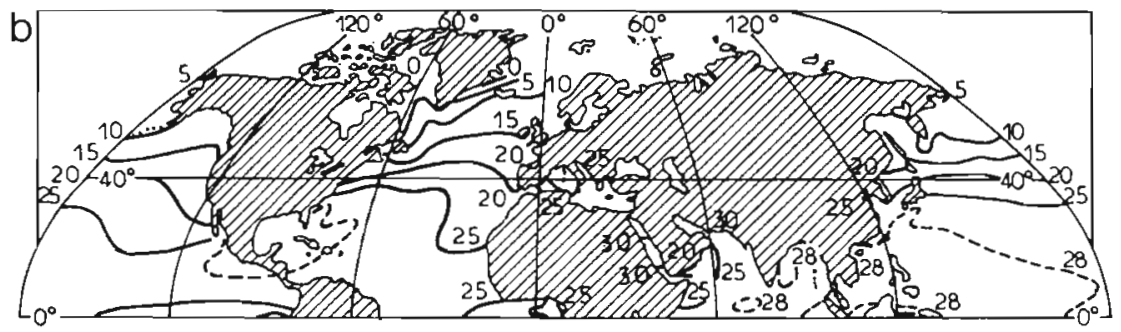


populations of capelin in the Arctic are most likely of postglacial origin and may represent relict populations of a wider Arctic distribution during the Holocene hypsithermal, the date of which varied with latitude and in the Arctic occurred 4500 to 6000 yr ago (Hattersley-Smith 1972, Hopkins 1972, Alt 1983).

It is worthy of mention that capelin spawning intertidally have the ancestral number of vertebrae as opposed to the deep-spawners that have a more derived number of vertebrae (Table 1). Hence, this scenario would be disproved should a stock of deepspawning capelin be found in the Pacific ocean.

This evolutionary ecological scenario may also apply to other fisheries. Herring exhibits a differentiation with regard to spawning mode similar to that of capelin. It spawns intertidally in the North Pacific and on sediments offshore in the North Atlantic. This, and other aspects of its reproductive biology, parallel those of capelin (see Blaxter 1985 for a review), may be explained by this scenario. Other investigators have also related glacial-interglacial cycles to speciation of both marine (e.g. Nesis 1984: arctic marine benthos; Grant et al. 1984: Pacific halibut) and land biota (e.g. Gould 1969: land snails; Budyko 1977: man's ancestors).

Important in this scenario is not the tempo (i.e. when this took place) but the mode (i.e. how this was mediated); in other words it is the effect of the glacialinterglacial cycle(s) on the distribution and differentiation of capelin throughout its range that concerns us. Although the scenario proposed here is placed, with respect to time, in the last glacial-interglacial cycle ( 75000 to 0 yr Before Present) (because this cycle has been extensively studied and the paleoceanography of the seas has been successfully reconstructed), the same argument may hold for any other Pleistocene glacialinterglacial cycle. In this context, the capelin, which propably evolved in the Pacific (McAllister 1963), equipped with mechanisms of dispersal (pelagic larvae) and with mechanisms favoring rapid population growth (high fecundity) - essential characteristics of an opportunist, r-strategist - penetrated the North Atlantic via the Bering Sea/Arctic Ocean route, when conditions for dispersal were optimum (open strait either due to glacio-eustatic sea level changes or geological reasons). During the following glacial period the $r-$ selected populations of capelin were subjected to $k$ selection to produce endemic populations of capelin in the North Atlantic that were able to reproduce in the new conditions (spawning at depth).

Undoubtedly, such widely separate populations of capelin are unlikely to be panmictic and genetic differences are expected to be established (distancedependent gene flow, isolation by distance). Indeed Payne $(1975,1976)$ found, using electrophoretic analy- sis of liver and skeletal muscle esterases, that populations of capelin from Northwest Territories, Newfoundland and Greenland are genetically distinct. Isolation by distance has been also found in cod throughout the North Atlantic (Mork et al. 1985), Pacific herring (Grant \& Utter 1984) and Pacific halibut (Grant et al. 1984). There remains the question to what degree the populations of capelin of the North Pacific-Northwest Atlantic and Central-Northeast Atlantic represent taxonomically distinct groups (subspecies, incipient species, species). Multivariate discriminant analysis performed on morphometric characters of capelin from the Gulf of St. Lawrence, Newfoundland and Grand Banks (Sharp et al. 1978, Carscadden \& Misra 1979), as well as data on the seasonal distribution and possible migration patterns of capelin in the Newfoundland area (Campbell \& Winters 1973), indicate that the populations of deep-spawning capelin on the Grand Banks and Newfoundland are distinct. It cannot be stated with certainty, however, that these populations are reproductively isolated. Larvae from these 2 areas intermingle by means of the Labrador current system (Sharp et al. 1978). Nevertheless, the spawning behaviors described above are closely related to stock separation.

In the Barents Sea, 2 stocks can be distinguished. A major oceanic stock, which spawns offshore, thrives in the northern part of the sea during summer and starts its spawning migration to the Norwegian and Soviet coast in autumn (Prokhorov 1965, Loeng et al. 1983, Stergiou 1984). Minor stocks, which spawn intertidally, permanently inhabit various Norwegian fjords (Sars 1879, Davenport et al. 1979, Davenport \& Stene 1986). However, analysis of tissue extracts from oceanic and fjord capelin by means of isoelectric focusing and histochemical enzyme detection failed to prove reproductive isolation between the 2 stocks (Mork \& Friis-Sörensen 1983).

Thus the confirmation of the existence of 2 distinct taxonomic groups of capelin remains open for further study. Morphometric, meristic, genetic and behavioral characteristics of populations from different localities in the Pacific, Atlantic and Arctic oceans must be systematically compared. Nevertheless, it is now possible to conclude that the contemporary differentiation of capelin into 2 recognizably different groups (subspecies, incipient species or species) is probably the result of geographic isolation for a period of less than $100000 \mathrm{yr}$. If this scenario is correct, speciation rates for this genus of fish, at least, should be reckoned in thousands of years, not longer.

Acknowledgements. The author thanks Drs B. M. Marcotte and $M$. J. Dunbar for their invaluable assistance in reading the manuscript and making many constructive criticisms and suggestions, and is grateful for the great hospitality and the use of the excellent library of McGill University. Many thanks are due to $M$. Cheilakea for typing the references. 


\section{LITERATURE CITED}

Alt, B. T (1983). Synoptic analogs: a technique for studying climatic change in the Canadian high arctic. Syllogeus 49: 70-107

Altukhov, K. (1977). On the reproductive biology of the capelin (Mallotus villosus) in the White Sea. J. Icthyol. 17 $410-416$

Andriyashev, A. P. (1964). Fishes of the Northern Seas of the USSR. National Science Foundation, Israel Program for scientific translations. Jerusalem

Anonymous (1974). The spawning migration of capelin during the winter of 1974. Fisk. Gang 60: 713-718 (Norwegian; English abstract)

Anonymous (1975). Investigations on capelin and cod in the Barents Sea during the winter of 1975. Fisk. Gang 62: 69-73 (Norwegian; English abstract)

Arsenault, M. (1979). Etude morphologique de poissons fossiles de la mer de Champlain (Pleistocène supérieur), en provenance de Green Creek, Ottawa. Quelques aspects paléologiques. M.Sc thesis, University of Québec

Backus, R. H. (1957). The fishes of Labrador. Bull. Am. Mus. nat. Hist. 113: 273-337

Bailey, R. J. F., A.ble, K., Leggett, W. C. (1977). Seasonal and vertical distribution and growth of juvenile and adult capelin (Mallotus villosus) in the St. Lawrence estuary and western Gulf of St. Lawrence. J. Fish. Res. Bd Can 34: 2030-2040

Barash, M. S., Os kina, N. S. (1979). Paleotemperatures of the Atlantic Ocean 18,000 and 40,000 years ago (based on planktonic foraminifera). Oceanology 19: 59-63

Berger, W. H., Killingley, J. S., Vincent, E. (1985). Timing of deglaciation from an oxygen isotope curve for Atlantic deep-sea sediments. Nature, Lond. 314: 156-158

Bigelow, H. B. (1963). Family Osmeridae. Mem. Sears Fdn mar. Res. 1: 533-597

Bigelow, H. B., Schroeder, W. C. (1953). Fishes of the Gulf of Maine. U.S. Fish. Wildl. Serv. Fish. Bull. 74: 1-577

Bigelow, H. B., Welsh, W. W. (1924). Fishes of the Gulf of Maine. Bull. U.S. Bur Fish. 40: 142-143

Bjørke, H., Gjøsæter, J., Sætre, J. (1972). Investigations at the spawning grounds of capelin in 1972. Fisk. Gang 58: 710-716 (Norwegian; English abstract)

Blaxter, J. H. S. (1985). The herring: a successful species? Can. J. Fish. Aquat. Sci. 42: 21-30

Boellstorff, J. (1978). North American Pleistocene stages reconsidered in light of probable Pliocene-Pleistocene continental glaciation. Science 202: 305-307

Budyko, M. I. (1974). Climate and life. Int. Geophys. Ser. 18: $1-508$

Budyko, M. I. (1977). Climatic changes. American Geophysical Union, Washington, D.C.

Campbell, J. S., Winters, G. H. (1973). Some biological characteristics of capelin, Mallotus villosus, in the Newfoundland area. Int. Cornm. Northwest Atl. Fish. Res. Doc. 73/90, Ser. No. $3048: 8$ p.

Carscadden, J. E. (1978). The capelin, Mallotus villosus, population spawning on the Southeast Shoal of the Grand Bank, 1976. Int. Comm. Northwest Atl. Fish. Sel. Pap. 3: 61-71

Carscadden, J. E., Misra, R. K. (1979). Multivariate analysis of meristic characters of capelin (Mallotus villosus) in the Northwest Atlantic. Can. J. Fish. Aquat. Sci. 37: 725-729

Clemens, W. A., Wilby, G. V. (1961). Fishes of the Pacific coast of Canada. Bull. Fish. Res. Bd. Can. 68: 1-443

CLIMAP (1976). The surface of the Ice-Age Earth. Science 191: 1131-1137
Colinvaux, P. (1986). Ecology. John Wiley \& Sons, New York

Connell, J. H., Orias, E. (1964). The ecological regulation of species diversity. Am. Nat. 98: 399-414

Corlett, J. (1968). Capelin in the northwestern Barents Sea. Rapp. P.-v. Réun. Cons. Perm. int. Explor. Mer 158: 11-18

Cumming, J. G. (1975). The recent development of the Norwegian capelin fishery. Geography 60: 40-42

Davenport, J., Stene, A. (1986). Freezing resistance, temperature and salinity tolerance in eggs, larvae and adults of capelin, Mallotus villosus, from Balsfjord. J. mar. biol. Ass. U.K. 66: 145-157

Davenport, J., Vahl, O., Lönning, S. (1979). Cold resistance in the eggs of the capelin Mallotus villosus. J. mar biol. Ass. U.K. 59: 443-453

Dommasnes, A., Hamre, J. (1977). The spawning migration of capelin during the winter of 1977. Fisken Havet 1977 (3): 1-9 (Norwegian; English abstract)

Dommasnes, A., Midttun, L., Monstad, T. (1979). Capelin investigations in the Barents Sea during the winter 1978. Fisken Havet 1979 (1): 1-16 (Norwegian; English abstract)

Dragesund, O., Gjesæeter, J., Monstad, T (1973). Estimates of stock size and reproduction of the Barents Sea capelin in 1970-72. FiskDir. Skr. (Ser HavUnders.) 16: 105-139

Dragesund, O., Monstad, T. (1973). Observations on capelin (Mallotus villosus) in Newfoundland waters. Int. Comm. Northwest Atl. Fish. Res. Doc. 74/63, Ser. No. 3283: 4 p.

Dunbar, M. J. (1951). Eastern Arctic waters. Bull. Fish. Res. Bd Can 88: 1-131

Dunbar, M. J. (1968). Ecological development in Polar regions: a study in evolution. Prentice-Hall, Englewood Cliffs

Dunbar, M. J. (1972). The nature and definition of the marine subarctic, with a note on the sea-life area of the Atlantic salmon. Trans. R. Soc. Can. Sect. 4 10: 249-257

Dunbar, M. J. (1976). Climatic change and northern development. Arctic 29: 183-193

Dunbar, M. J. (1983). A unique international Polar year contribution: Lucien Turner, capelin and climatic change. Arctic 36: 204-205

Emiliani, C. (1972). Quaternary hypsithermal. Quat. Res. (N.Y.) 2: $270-273$

FAO (1987). Year book of fishery statistics, 1985. Vol. 57. FAO, Rome

Fitzpatrick, C., Miller, R. (1979). Review of spawning times and locations for some commercial finfish on the Newfoundland and Labrador coast. Can. Fish. Mar. Serv. Tech. Rep. 905: $14 \mathrm{p}$.

Frank, K. T., Leggett, W. C. (1981a), Prediction of egg development and mortality rates in capelin (Mallotus villosus) from meteorological, hydrographic, and biological factors. Can. J. Fish. Aquat. Sci. 38: 1327-1338

Frank, K. T., Leggett, W. C. (1981b). Wind regulation of emergence time and early larval survival in capelin (Mallotus villosus). Can. J. Fish. Aquat. Sci. 38: 215-223

Frank, K. T., Leggett, W. C. (1982a). Environmental regulation of growth rate, efficiency, and swimming performance in larval capelin (Mallotus villosus), and its application to the match/mismatch hypothesis. Can. J. Fish. Aquat. Sci. 39: 691-699

Frank, K. T., Leggett, W. C. (1982b). Coastal water mass replacement: its effect on zooplankton dynamics and the predator-prey complex associated with larval capelin (Mallotus villosus). Can. J. Fish. Aquat. Sci. 39: 991-1003

Fridriksson, A. (1943). Contributions to the knowledge of the Icelandic capelin (Mallotus villosus O. F. Müller). Rit. Visindafj. isl. 2: 189-197 
Fridriksson. A (1948). Boreo-tended changes in the marine vertebrate fauna of Iceland during the last 25 years. Rapp. P.-v. Réun Cons, int. Explor. Mer 25: 30-32

Fries, B. C., Ekström, U., Sunderall, C. (1895). A history of Scandinavian fishes, 2nd edn, Part II. (Revised and supplemented by F. A. Smitt.) Norstedt and Söner, London

Galkin, A. S. (1973). Soviet investigations on capelin in the spawning period in 1971. Annls biol. 28: 200-202

Galkin, A. S. (1975). Soviet capelin investigations in the spring of 1973. Annls biol. 30: 168-169

Galkin, A. S., Kovalev, S. M. (1975). Fecundity of the capelin Mallotus villosus of the Barents Sea. J. Icthyol. 15: 579-583

Galkin, A. S., Luka, G. I. (1976). Soviet investigations on the Barents Sea capelin in spring 1974. Annls biol. 31: 156

Galkin, A. S., Shulga, A. D. (1977). Soviet investigations on the Barents Sea capelin in the spring 1975. Annls biol. 32:159

Galkin, A. S., Ushakov, N. G. (1978). Soviet investigations on the Barents Sea capelin in 1976. Annls biol. 33: 150-151

Galkin, A. S., Ushakov, N. G. (1979). Soviet investigations on the Barents Sea capelin in 1977. Annls biol. 34: 199-200

Galkin, A. S., Ushakov, N. G. (1980). Soviet investigations on the Barents Sea capelin in 1978. Annls biol. 35: 209

Galkin, A. S., Ushakov, N. G. (1981). Soviet investigations on the Barents Sea capelin in 1979. Annls biol. 36: 171

Galkin, A. S., Ushakov, N. G. (1983). Soviet investigations on the Barents Sea capelin in 1980. Annls biol. 37: 227-228

Gjøsæter, J., Hansen, K., Sæetre, R., Westergaard, T. (1974). Investigations at the spawning grounds of capelin in 1974. Fisk. Gang 60: 740-744 (Norwegian; English abstract)

Gjøsater, J., Loeng, H. (1987). Growth of the Barents Sea capelin, Mallotus villosus, in relation to climate. Environ. Biol. Fish 20: 293-300

Gjøsæter, J., Martinsen, O. (1975). Investigations at the spawning grounds of capelin in 1975. Fisk. Gang 62: 30-32 (Norwegian; English abstract)

Gjesæeter, J., Monstad, T (1973). Fecundity and egg size of spring spawning Barents Sea capelin. FiskDir. Skr. (Ser HavUnders.) 16: 98-104

Gjosæter, J., Sætre, R. (1973). Investigations at the spawning grounds of capelin in 1973. Fisk. Gang 59: 745-748 (Norwegian; English abstract)

Gould, S. J. (1969). An evolutionary microcosm: Pleistocene and recent history of the land snail P. (Poecilozonits) in Bermuda. Bull. Mus. comp. Zool. (Harv.) 138: 407-532

Grant, S. W., Teel, D. J., Kobayashi, T., Schmitt, C. (1984). Biochemical population genetics of Pacific halibut (Hippoglossus stenolepis) and comparison with Atlantic halibut (H. hippoglossus). Can. J. Fish. Aquat. Sci. 41: 1083-1088

Grant, S. W., Utter, F. M. (1984). Biochemical population genetics of Pacific herring (Clupea pallasi). Can. J. Fish. Aquat. Sci. 41: 856-864.

Grassle, F. J., Sanders, H. L. (1973). Life histories and the role of disturbance. Deep Sea Res. 20:643-659

Grootes, P. M. (1978). Carbon-14 time scale extended: comparisons of chronologies. Science 200: 11-15

Hamre, J., Sætre, R. (1976). The spawning migration of capeLin during the winter of 1976 . Fisken Havet 1976 (2): 43-51 (Norwegian; English abstract)

Hansen, P. M. (1943). Capelin (Mallotus villosus). Annls biol. $1121-124$

Hansen, P. M., Hermann, F. (1953). Fisken og havet red Gronland. Skr. Dan. Fisk. Havunders. 15: 85-88

Hardy, C. (1867). On the capelin (Mallotus villosus). Proc. Trans. N. S. Inst. Sci. 1. (2): $4-13$

Hart, J. L. (1973). Pacific fishes of Canada. Bull. Fish. Res. Bd Can. 180: 1-740
Hart, J. L., McHugh, J. L. (1944). The smelts (Osmeridae) of British Columbia. Bull. Fish. Res. Bd Can. 64: 1-27

Harvey, J. G. (1976). Atmosphere and ocean. Artemis Press, Horsham

Hattersley-Smith, G. (1972). Climatic change and related problems in northern Ellesmere Island, N. W T., Canada. Acta. Univ. Oulu A3, Geol. 1. 137-148

Hjort, J. (1914). Fluctuations in the great fisheries of Northern Europe viewed in the light of biological research. Rapp. P. v. Réun. Cons. Perm. int. Explor. Mer 20: 1-228

Hopkins, D. M. (1972). The paleoceanography and climatic history of Beringia during late Cenozoic time. Inter-Nord 12: $121-150$

Huntsman, A. G. (1922). The fishes of the Bay of Fundy. Contr. Can. Biol. Fish. 3: 49-72

Jakobsen, T., Nakken, O. (1973). Capelin investigations with R. V 'G. O. Sars' in the Barents Sea in February-March 1973. Fisken Havet 1973 (3): 43-46 (Norwegian; English abstract)

Jangaard, P. M. (1974). The capelin (Mallotus villosus): biology, distribution, exploitation, utilization, and composition. Bull. Fish. Res. Bd Can. 186: 1-70

Jeffers, G. W (1931). The life history of the capelin Mallotus villosus (O. F. Müller). Ph.D. thesis, University of Toronto

Jensen, A. S. (1925). The fishery of the Greenlanders. Kjobenhavn Medd. Hav. 7 (7): 23-24

Jensen, A. S. (1939). Concerning a change of climate during recent decades in the Arctic and Subarctic regions, from Greenland in the west to Eurasia in the east, and countemporary biological and geophysical changes. Biol. Meddr. 14: 1-83

Jensen, A. S. (1948). Contributions to the icthyo-fauna of Greenland. Spolia Zool. Mus. Hauniensis 9: 1-182

Jespersen, P. (1920). On the occurrence of the post-larval stages of the herring and the 'lodde' (Clupea harengus $\mathrm{L}$. and Mallotus villosus (O. F. M.)) at Iceland and the Faroes. Meddr. Kommn Havunders. (Ser. Fiskeri) 6 (1): 1-24

Kanneworff, P. (1968). Preliminary results and some problems concerning capelin investigations at Greenland. Rapp. P.v. Réun. Cons. Perm. int. Explor. Mer 158: 38-40

Kendall, W. C. (1909). The fishes of Labrador. Portland Soc. Nat. Hist. Proc. 2: 207-243

Kendall, W. C. (1917). The capelin (Mallotus villosus) with notes on its occurrence on the coast of Maine. Copeia 42 $28-30$

Kendall. W C. (1919). Second authentic record of capelin (Mallotus villosus) on the Maine coast. Copeia 73: 70-71

Kljukanov, V. A. (1972). On the systematic relationship of the Atlantic and Pacific forms of Mallotus villosus (Müller) and osteological characteristics of the genus Mallotus (Pisces Osmeridae). Zool. Zh. 51: 855-862 (Russian)

Kljukanov, V A., McAllister, D. E. (1979). Osmeridae. In: Tortonese, E., Hureau, J. C. (eds.) Check-list of the fishes of the North-eastern Atlantic and of the Mediterranean, Vol. I. UNESCO, Paris, p. 158-159

Klochkov, D. N., Seliverstov, A. S. (1978). Assessment of abundance and biomass of the spawning stock of capelin in ICNAF Division $3 N$ in summer of 1977. Int. Comm. Northwest A.tl. Fish. Res. Doc. 78/VI/29 Ser. No. 5190: 6 p

Konstantinov, K. (1965). Water temperature as a factor guiding fishes during their migrations. Int. Comm. Northwest Atl. Fish. Spec. Publ. 6: 221-224

Konstantinov, L., Svetlov, I. (1974). Temporal relationship between water temperature and distribution of some commercial marine fishes. Oceanology 14: 283-287

Kovalyov, S. M. (1972). Soviet investigations on capelin in 1970. Annls biol. 27: 177-178 
Kovalyov, S. M., Benko, Yu. (1970). Soviet investigations on capelin in the spring, 1966-1969. Annls biol. 26: 268-269

Kovalyov, S. M., Galkin, A. S. (1974). Soviet investigations on capelin in the Barents Sea in January-May 1972. Annls biol. 29: 163-164

Leggett, W. C., Frank, K. T., Carscadden, J. E. (1984). Meteorological and hydrographic regulation of year-class strength in capelin (Mallotus villosus). Can. J. Fish. Aquat. Sci. 41 1193-1201

Loeng, H., Nakken, O., Raknes, A. (1983). The distribution of capelin in the Barents Sea in relation to the water temperature in the period 1974-1982. Fisken og Havet 1983 (1): 1-17 (Norwegian; English abstract)

MacArthur, R. H., Wilson, E. O. (1967). The theory of island biogeography. Princeton University Press, Princeton, New Jersey

Magnusson, J. (1966). On capelin (Mallotus villosus O. F. Müller) in Icelandic waters during the years 1960 to 1964 , with some notes on other fish larvae. Rit. Fiskideildar. 4: $1-36$

Magnusson, J. (1968). On the occurrence of capelin larvae in Icelandic waters in relation to temperature Rapp. P.-v. Réun. Cons. Perm. int. Explor. Mer 158: 31

Malmberg, S. A. (1983). Hydrographic conditions in Icelandic waters in May/June 1979 and 1980. Annls biol. 37: 47-56

Mason, B. J. (1976). Towards the understanding and prediction of climatic variations. Q. J. r. meteorol. Soc. 102: $473-498$

Matthews, S. W. (1976). What is happening to our climate. Natn. geogr. Mag. 150: 576-615

Mattox, W. G. (1973). Fishing in West Greenland 1910-1966: the development of a new native industry. Meddr Gronland 197: 1-344

McAllister, D. E. (1962). Fishes of the 1960 'Salvelinus' program from western Arctic Canada. Nat. Mus. Can. Bull. 185: 17-39

McAllister, D. E. (1963). A revision of the smelt family Osmeridae. Nat. Mus. Can. Bull. 191: 1-53

McA.llister, D. E. (1964). Fish collections from eastern Hudson Bay. Can. Fld Nat. 78: 167-178

McAllister, D. E. (1984). Osmeridae. In: Whitehead, P. J. P., Bauchot, M. L., Hureau, J. C., Tortonese, E. (eds.) Fishes of the North-Eastern Atlantic and the Mediterranean, Vol. I. UNESCO, Paris, p. 399-402

Midttun, L., Nakken, O. (1977). Some results of abundance estimation studies with echo integrators. Rapp. P.-v. Réun. Cons. int. Explor. Mer 170: 253-258

Miller, D. S., Carscadden, J. E. (1979). Biological characteristics and biomass estimates of capelin in ICNAF Div. $2 \mathrm{~J}+3 \mathrm{~K}$ using a sequential capelin abundance model. Int. Comm. Northwest Atl. Fish. Res. Doc. 79/II/32 Ser. No. 5358: 10 p.

Moller, D., Olsen, S. (1962). Norwegian capelin investigations. Coun. Meet. int. Coun. Explor. Sea C.M.-ICES/34: 1-10

Mori, T. (1930). On the freshwater fishes from Tumen River, Korea, with descriptions of new species. J. Chosen Nat. Hist. Soc. 11: 1-11

Mork, J., Friis-Sörensen, E. (1983). Genetic variation in capeLin, Mallotus villosus, from Norwegian waters. Mar. Ecol. Prog. Ser. 12: 199-205

Mork, J., Ryman, N., Utter, F, Sundnes, G. (1985). Genetic variation in Atlantic cod (Gadus morhua) throughout its range. Can. J. Fish. Aquat. Sci. 42: 1580-1587

Nakken, O., Dommasnes, A. (1975). The application of an echo integration system in investigations of the stock strength of the Barents Sea capelin (Mallotus villosus Müller) 1971-1974. Coun. Meet. int. Coun. Explor. Sea C.M.ICES/B 25: 20 p. [Mimeo]
Naumenko, E. A. (1984). Diet of Pacific capelin, Mallotus villosus socialis (Osmeridae), in the Bering Sea. J. Icthyol. 24: $130-134$

Nesis, K. N. (1984). A hypothesis on the origin of western and eastern arctic distribution areas of marine bottom animals. Soviet J. mar. Biol. 9: 235-243

Nikiforovskaya, T D. (1933). Races of capelin off the Murman coast. Trudy gos. okeanogr. Inst. 4: 55-64 (Russian)

Olsen, S. (1968). Some results of the Norwegian capelin investigations 1960-1965. Rapp. P.-v. Réun. Cons. Perm. int. Explor. Mer 158: 18-23

Ortmann, A. (1896). Grundlage der marinen Tiergeographie. G. Fischer, Jena

Ozhigin, V. K., Luka, G. I. (1985) Some peculiarities of capelin migrations depending on thermal conditions in the Barents Sea. In: Gjøsæter, H. (ed.) Proceedings of the SovietNorwegian Symposium on the Barents Sea capelin, Bergen, August 1984. Institute of Marine Research, Bergen, p. 135-147

Ozhigin, V. K., Ushakov, N. G. (1985). The effect of the thermal conditions of the sea and atmospheric circulation on the distribution of the Barents Sea capelin feeding areas. In: Gjosæter, H. (ed.) Proceedings of the Soviet-Norwegian Symposium on the Barents Sea capelin, Bergen, August 1984. Institute of Marine Research, Bergen, p. 149-156

Parent, S., Brunel, P. (1976). Aires et périodes de fraye du capelan (Mallotus villosus) dans l'estuaire et le Golfe du Saint-Laurent. Trav. Pech. Qué. 45: 1-46

Pashkova, T (1975). The occurrence of spawning capelin (Mallotus villosus villosus) in Indiga Bay in the Barents Sea. J. Icthyol. 14: 802-803

Payne, R. H. (1975). Esterase polymorphism in the capelin, Mallotus villosus: preliminary evidence for geographical variation in allele frequencies at three loci. Coun. Meet. int. Coun. Explor Sea C.M.-ICES/H 28: 9 p.

Payne, R. H. (1976). Further studies on the biochemical population genetics of the capelin, Mallotus villosus: demonstration that the capelin populations of West Greenland and North America were genetically distinct. Coun. Meet. int. Coun. Explor. Sea C.M.-ICES/H 24: 7 p.

Perley, M. H. (1859). Report on the fisheries of the Gulf of St Lawrence. Can. Nat. Geol. 4:40-56

Pianka, E. R. (1970). On r- and k-selection. Am. Nat. 104: 592-597

Pitt, T. K. (1958). Distribution, spawning and racial studies of the capelin Mallotus villosus (Müller) in the offshore Newfoundland waters. J. Fish. Res. Bd Can. 15: 275-293

Pozdnyakov, Yu. F. (1957). The fecundity of capelin in the Barents Sea. Dokl. Akad. Nauk SSSR 112: 777 (Russian)

Pozdnyakov, Yu. F. (1959). Spawning of capelin in an aquarium. Izv. Karal'. Kol'sk. Vil. Akad. Nauk. SSSR 3: 145-147 (Russian)

Pozdnyakov, Yu. F. (1962). Distribution of capelin larvae in the southern and southeastern part of the Barents Sea. Trans. Murmansk Biol. Inst. 4: 134-145 (Russian)

Prokhorov, V. S. (1965). The ecology of capelin in the Barents Sea and perspectives of the fishery. Fish. Res. Bd Can. Trans. Ser. 813: $70 \mathrm{p}$.

Prokhorov, V. S. (1968). Materials on the ecology of capelin in the Barents Sea. Rapp. P.-v. Réun. Cons. Perm. int. Explor. Mer 158: 23-31

Rass, T. S. (1933). Spawning of the Barents Sea capelin (Mallotus villosus Müller). Trudy gos. okeanogr. Inst. 4: 3-35 (Russian)

Raup, D. M., Gould, S. J. (1974). Stochastic simulation and evolution of morphology - towards a nomothetic paleontology. Syst. Zool. 23: 305-322 
Rumyantsev, A. I. (1946). Capelin in the Japan Sea. Izv TINRO 22: 35-74 (Russian)

Saemundsson, B. S. (1934). Probable influence of changes in temperature on the marine fauna of Iceland. Rapp. P.-v. Réun. Cons. Perm. int. Explor Mer 1: 1-6

Sætre, R., Gjosæter, J. (1975). Ecological investigations on the spawning grounds of the Barents Sea capelin. FiskDir. Skr. (Ser. HavUnders.) 16: 203-227

Sanders, H. L. (1968). Marine benthic diversity: a comparative study. Am. Nat. 102: 243-282

Sars, G. O. (1879). Report submitted to the department of the Interior on the practical and scientific investigations of the Finmark capelan-fisheries, made during the spring of the year 1879. Rep. U.S. Comm. Fish and Fish. 8: 167-187

Savicheva, E. A. (1975). Soma data on the biology of capelin from the Western Kamchatka coast. Izv. Tikhookern. Nauchno-Issled. Inst. Rybn, khoz. okeanogr. 97: 45-50 (Russian)

Savicheva, E. A. (1982). Embryonic development of the Pacific capelin, Mallotus villosus socialis (Osmeridae), in the eastern Okhotsk Sea. J. Icthyol. 22: 69-74

Schmidt, P. Y (1965). Fishes of the Sea of Okhotsk. National Science Foundation, Israel Program for Scientific Translations, Jerusalem

Schultz, P. L. (1937). Redescription of the capelin Mallotus catervarious (Pennant) of the North Pacific. Proc. U.S. natn. Mus. 85: 13-20

Scott, G. K., Fletcher, G. L., Davies, P. L. (1986). Fish antifreeze proteins: recent gene evolution. Can. J. Fish. Aquat. Sci. 43: 1028-1034

Serebrov, L. I., Bakanev, V. S., Kovalev, S. M. (1975). The state of Newfoundland capelin stock. Int. Comm. Northwest Atl. Fish. Res. Doc. 75/7, Ser. No. 3435: 11 p.

Sharp, J. C., Able, K. W., Leggett, W. C., Carscadden, J. E. (1978). Utility of meristic and morphometric characters for identification of capelin (Mallotus villosus) stocks in Canadian Atlantic waters. J. Fish. Res. Bd Can. 35: 124-130

Sleggs, G. F. (1933). Observations upon the economic biology of the capelin (Mallotus villosus O. F. Müller). Nfld Fish. Res. Comm. Rep. 1: 1-66

Slobodkin, B. L., Rapport, A. (1974). An optimal strategy of evolution. Q. Rev. Biol. 49: 181-200

Slobodkin, L. B., Sanders, H. L. (1969). On the contribution of environmental predictability to species diversity. Brookhaven Symp. Biol. 22: 82-93

Stergiou, I. K. (1984). Capelin (Mallotus villosus) and climatic change in the Barents Sea. M.Sc. thesis, Institute of Oceanography, McGill University

Stuiver, M., Heusser, C. J., Yang. I. C. (1978). North American glacial history extended to 75,000 years ago. Science 200: $16-21$

Taning, A. V. (1948). On changes in the marine fauna of the Northwest Atlantic area, with special reference to Greenland. Rapp. P.-v. Réun. Cons. Perm. int. Explor Mer 25: 26-29

Taylor, C. C., Bigelow, H. B., Graham, H. W. (1957). Climatic trends and distribution of marine animals in New England. U.S. Fish. Wildl. Serv. Fish. Bull. 57: 293-345

Templeman, W (1948). The lite history of the capelin (Mallotus villusus O. F. Miller) in Newfoundland waters. Nfld Gov. Lab. Bull. 17: 1-151

Templeman, W. (1965). Mass mortalities of marine fishes in the Newfoundland area presumably due to low temperatures. Int. Comm. Northwest Atl. Fish. Spec. Publ. 6: $449-461$

Templeman, W (1968). Review of some aspects of capelin

This article was submitted to the editor biology in the Canadian area of the Northwest Atlantic. Rapp. P.-v. Réun. Perm. Cons. int. Explor. Mer 158: 41-53

Templeman, W., Fleming, A. (1953). Long term changes in hydrographic conditions and corresponding changes in the abundance of marine animals. Int. Comm. Northwest Atl. Fish. Ann. Proc. 3: 79-86

Thiede, J. (1978). A glacial Mediterranean. Nature, Lond. 276 : $680-683$

Thiery, R. G. (1982). Environmental instability and community diversity. Biol. Rev. 57: 691-710

Thors, K. (1981). Environmental features of the capelin spawning grounds south of Iceland. Rit. Fiskdeildar. 6: 7-13

Tibbo, S. N., Humphreys, R. D. (1966). An occurrence of capelin (Mallotus villosus) in the Bay of Fundy. J. Fish. Res. Bd Can. 23: 463-467

Tibbo, S. N., Messieh, S. N. (1967). Capelin. Fish. Res. Bd Can. St. Andrews Biol. St. Ann. Rep. 1967: 26-27

Velikanov, A. Ya. (1984). Ecology of reproduction of the Fareastern capelin, Mallotus villosus socialis (Osmeridae), along the coasts of Sakhalin. J. Icthyol. 24 (3): 43-48

Velikanov, A. Ya. (1987). Fecundity of the Far East capelin, Mallotus villosus socialis, in the coastal water of Sakhalin. J. Icthyol. 27: 87-96

Vibe, C. (1967). Arctic animals in relation to climatic fluctuations. Meddr Grenland 170: 1-227

Vilhjálmsson, H. (1968). A contribution to the knowledge of the Icelandic capelin. Rapp. P.-v. Réun. Cons. Perm. int. Explor. Mer 158: 32-38

Vilhjálmsson, H. (1979). Icelandic capelin investigations in 1977. Annls biol. 34: 196-199

Vilhjálmsson, H. (1980). Icelandic capelin investigations in 1978. Annls biol 35: 206-208

Vilhjálmsson, H. (1981). Icelandic capelin investigations in 1979. Annls biol. $36: 167-170$

Vilhjálmsson, H. (1983). Icelandic capelin investigations in 1980. Annls biol. 37: 225-227

Vilhjálmsson, H. (1984). Icelandic capelin investigations in 1981. Annls biol. 38: 151-153

Vilhjálmsson, H. (1985). Icelandic capelin investigations in 1982. Annls biol. 39: 151-153

Vilhjálmsson, H. (1986). Icelandic capelin investigations in 1983. Annls biol. 40: 143-145

Vadykov, V D. (1933). Biological and oceanographic conditions in Hudson Bay. Fishes from Hudson Bay region (except the Coregonidae). Contr. Can. Biol. Fish. (New Ser.) 8: 13-61

Walters, V (1955). Fishes of the western Arctic America and eastern Arctic Siberia. Taxonomy and zoogeography. Bull. Am. Mus. nat. Hist. 106: 259-368

Warner, B. G., Mathews, R. W., Clague, J. J. (1982). Ice-free conditions on the Queen Charlotte Islands, British Columbia, at the height of late Wisconsin glaciation. Science 218 : $674-677$

Winters, G H. (1969). Capelin (Mallotus villosus). In: Firth, F. E. (ed.) Encyclopedia of marine resources. Van Nostrand Reinhold, New York, p. 94-101

Winters, G. H. (1971). Fecundity of the left and right ovaries of Grand Bank capelin (Mallotus villosus). J. Fish. Res. Bd Can. 28: 1029-1033

Winters, G. H. (1975). Review of capelin ecology and estimation of surplus yield from predator dynamics. Int. Comm. Northwest Atl. Fish. Res. Doc. 75/2 No. 3430: 25 p

Woillard, G. M. Mook, W. G. (1982). Carbon-14 dates at Grande Pile: correlation of land and sea chronologies. Science 215: 159-161

Zenkevitch, L. (1963). Biology of the Seas of the USSR. Wiley Interscience, New York

Manuscript first received: March 9, 1988

Revised version accepted: June 1,1989 